Diabetologia $10,529-539(1974)$

(C) by Springer-Verlag 1974

\title{
Morphological Characterization of Membrane Systems in A- and B-Cells of the Chinese Hamster*
}

\author{
L. Orci, M. Amherdt, F. Malaisse-Lagae, A. Perrelet, W.E. Dulin, G.C. Gerritsen, W.J. Malaisse** and \\ A. E. Renold \\ Institut d'Histologie et d'Embryologie, Institut de Biochimie clinique, University of Geneva, Switzerland, and the \\ Upjohn Company, Kalamazoo, Michigan, USA
}

Summary. The nuclear and plasma membranes of islet cells from non-glycosuric and diabetic Chinese hamsters were examined by freeze-etching. The B-cells of diabetic animals presented a slight increase in the number of nuclear pores and marked alterations in the number, size and distribution of membrane-associated particles in the plasma membrane. In A-cells, identified by the presence of characteristic bundles of coarse filaments in the perinuclear region, a definite increase in the number of nuclear pores was found in the most severely diabetic animals.
These preliminary findings point to alterations in the membrane systems as possible determinants for the abnormalities of islet function in diabetes mellitus.

Key words: Chinese hamster, Cricetulus griseus, endocrine pancreas, islet of Langerhans, A-cells, B-cells, Dcells, spontaneous diabetes, nuclear pores, plasma membrane, membrane-associated particles, glycogen, ultrastructure, electron microscopy, freeze-etching.
In view of the major importance ascribed to membrane systems in the control of biological processes, we considered that a comparative investigation, by freezeetching, of such systems in A- and B-cells of normal and diabetic animals was timely. Freeze-etching, by exposing large areas of the inner matrix of membranes, allows their ultrastructural characterization in both qualitative and quantitative terms. First, however, one has to find out how to distinguish A- from B-cells in freezeetch replicas. Indeed, the usual criteria used in thinsectioned material, such as the electron density of the granule-core or its distance from the limiting membrane, are of no help in a freeze-etch preparation. Previous attempts to differentiate A- and B-cells in freezeetching were based sofar on such crude and indirect evidence as the location of the cells within the islets [1]. It is known for example that in some animal species, the center of the islet consists mostly of B-cells [2]. In the Chinese hamster, we have recognized a peculiar ultrastructural feature which offered a novel and secure way to identify A- and B-cell in freeze-etching, and which allowed us to investigate the organization of some membrane systems in each of these cell types.

\section{Material and Methods}

Thirty Chinese hamsters (Cricetulus griseus), 5 to 20 months old were selected from the colony main-

* Supported in part by the Fonds National Suisse de la Recherche Scientifique, (grants 3.8080.72, 3.0310.73, 3.0311 .73 and $3.1060 .73 \mathrm{SR}$ ), the Upjohn Company, Kalamazoo, Michigan, and a grant-in-aid from Hoechst Pharmaceuticals, Frankfurt Hoechst, Germany.

** Invited Professor at the University of Geneva, recipient of a Pfizer Travel Award through the E.A.S.D. tained at the Upjohn Company (Kalamazoo, Michigan) and classified into 3 age- and sex-matched groups on the basis of the following biological criteria. The "control" hamsters were derived from nondiabetic parents and had never presented glycosuria. The "diabetic but non ketotic" animals had shown a consistent Testape value of $4+$ and a negative Ketostix test for at least 4 months. The "diabetic and ketotic" hamsters were characterized by a positive Ketostix test for 1 to 5 months, associated with persistent glycosuria.

The hamsters were killed by decapitation after 18 to $24 \mathrm{~h}$ fasting. At that time, their mean plasma glucose level averaged $107 \pm 4,256 \pm 23$ and $320 \pm 13 \mathrm{mg} /$ $100 \mathrm{ml}$ for the control, non ketotic and ketotic hamsters respectively. All morphological studies were performed on islets isolated according to a standard procedure [3]. Islets for thin-section electron microscopy were fixed in $2 \%$ phosphate-buffered glutaraldehyde, post-fixed with buffered osmic acid, dehydrated with alcohol and embedded in Epon. For freeze-etching, approximately 100 islets obtained from 2 animals in the same group were pelleted, fixed in phosphate-buffered glutaraldehyde and infiltrated with a $30 \%$ solution of glycerol in phosphate buffer (cryoprotectant). They were then freeze-etched according to Moor and Mühlethaler [4] in a Balzers freeze-etching unit (BAF 301). The replicas and the ultrathin sections were examined in a Philips EM 300 electron microscope. Magnifications were calibrated with a reference grid (Fullam. Inc., 2160 lines $/ \mathrm{mm}$ ).

\section{Results and Discussion}

In examining replicas of Chinese hamster islets, we were struck by the presence of freeze-etch images of filaments in the perinuclear region of certain cells. In 


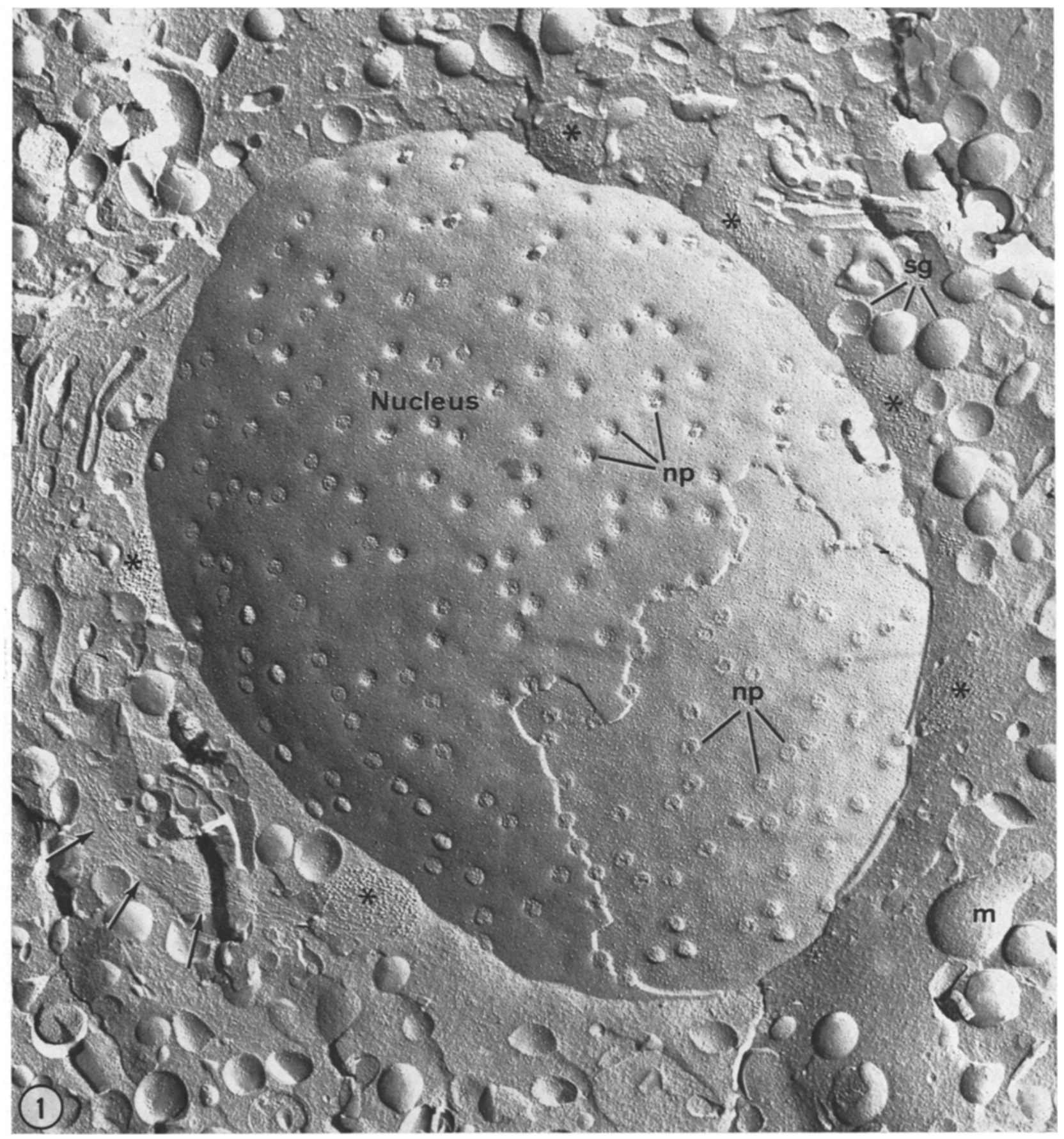

Fig. 1. Freeze-etch replica of an islet-cell from a Chinese hamster. The fracture process has split the nuclear envelope, revealing the nuclear pores $(\mathrm{np})$. In the cytoplasm surrounding the nucleus, both longitudinally(arrows) and cross-fractured (asterisks) filaments are seen. In this animal species the presence of such bundles of coarse filaments allows one to identify this cell type as an A-cell (see Fig. $2 \mathrm{a}$ ). sg $=$ secretory granules; $\mathrm{m}=$ mitochondrion. $(\times 27,000)$ 

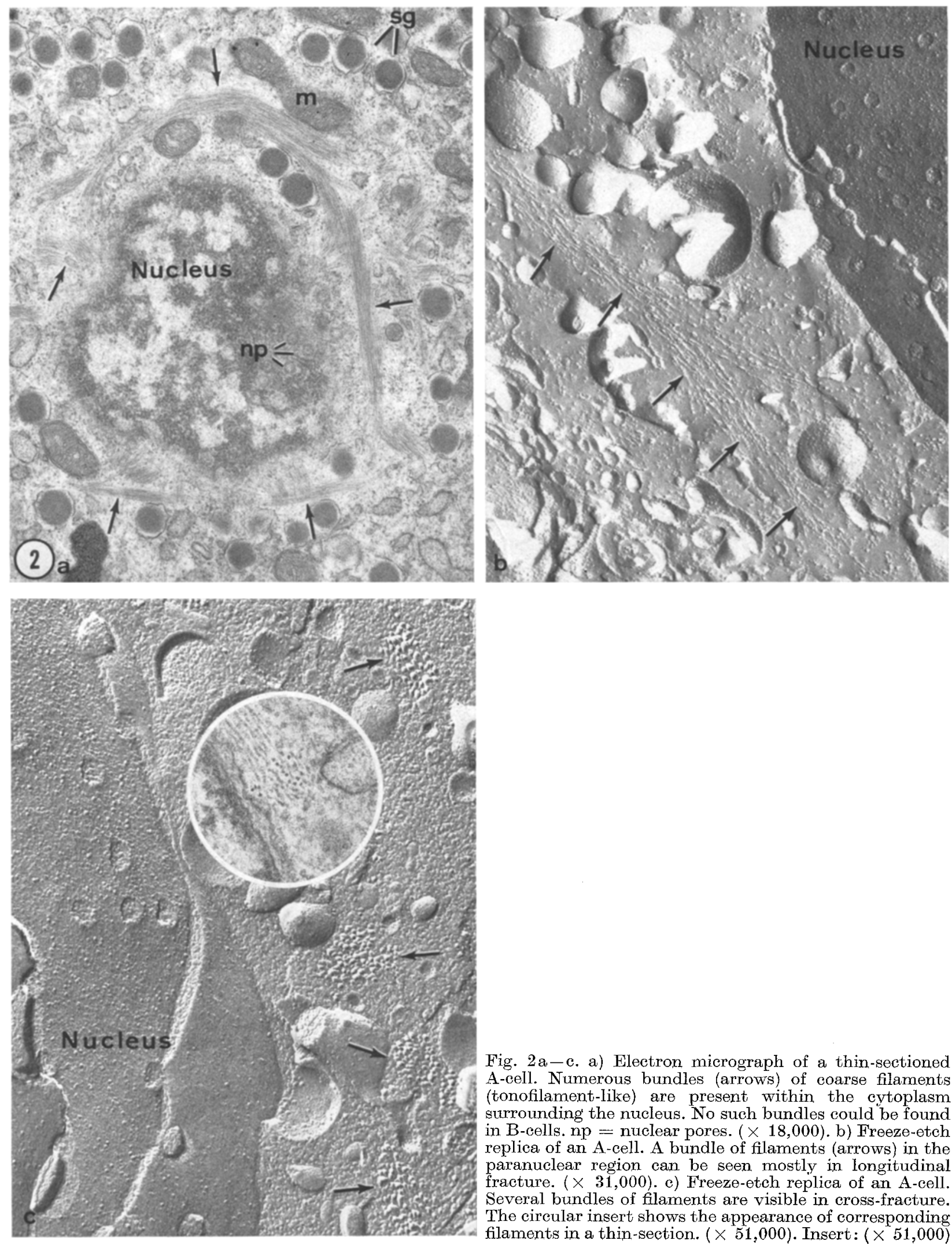

Fig. $2 a-c$ a) Electron micrograph of a thin-sectioned A-cell. Numerous bundles (arrows) of coarse filaments (tonofilament-like) are present within the cytoplasm. surrounding the nucleus. No such bundles could be found in B-cells. $n p=$ nuclear pores. $(\times 18,000)$. b) Freeze-etch replica of an A-cell. A bundle of filaments (arrows) in the paranuclear region can be seen mostly in longitudinal fracture. $(\times 31,000)$. c) Freeze-etch replica of an A-cell. Several bundles of filaments are visible in cross-fracture. The circular insert shows the appearance of corresponding filaments in a thin-section. $(\times 51,000)$. Insert: $(\times 51,000)$ 
freeze-etching, filaments appear either as dots protruding above the cytoplasmic fracture face (crossfracture) or as linear arrays disposed on the cytoplasmio surface (longitudinal fracture) (Figs. 1, 2b and 2c). In scrutinizing electron micrographs from thin-sectioned islets, we discovered that the counterpart of the freezeetched arrays and dots were present only in A-cells and consisted of numerous bundles of coarse filaments (Fig. 2a). These bundles were invariably present in the perinuclear region of all A-cells of the Chinese hamsters we have examined so far by conventional electron microscopy [5]. We identified, therefore, all cells showing numerous bundles of coarse filaments in freeze-etch replicas as $\mathrm{A}$-cells ${ }^{1}$.

The appropriate tools for both the examination of membranes and the identification of $\mathrm{A}$ - and $\mathrm{B}$-cells being thus available, we selected two membrane compartments which are easily visualized by freeze-etching and also bear considerable functional significance.
These two membrane compartments are the nuclear envelope and the plasma membrane, respectively (Fig. 4). Nucelear envelope is of particular significance since it is through the nuclear pores that the nucleocytoplasmic exchanges take place, exchanges which play a key role in the control of the biosynthetic activ.

1 Additional criteria can help distinguishing A- and B-cells but only in diabetic animals. B-cells from diabetic animals are frequently degranulated and may show con. spicuous deposits of glycogen which can be identified in freeze-etching (Fig. 3). Virtually no glycogen deposit is seen in A-cells of diabetic animals which are characterized by the frequent occurrence of multigranulated lysosomal bodies (crinophagy) [6]. Moreover, preliminary observations indicate that it is also possible to identify D-cells in freeze-etched islets. The secretory granules in $\mathrm{D}$-cells have a small size and a polymorphous shape which is easily recognizable in freeze-etch replicas. So far the number of D-cells encountered was too small for allowing any quantification of morphological parameters as performed in A. and B-cells.
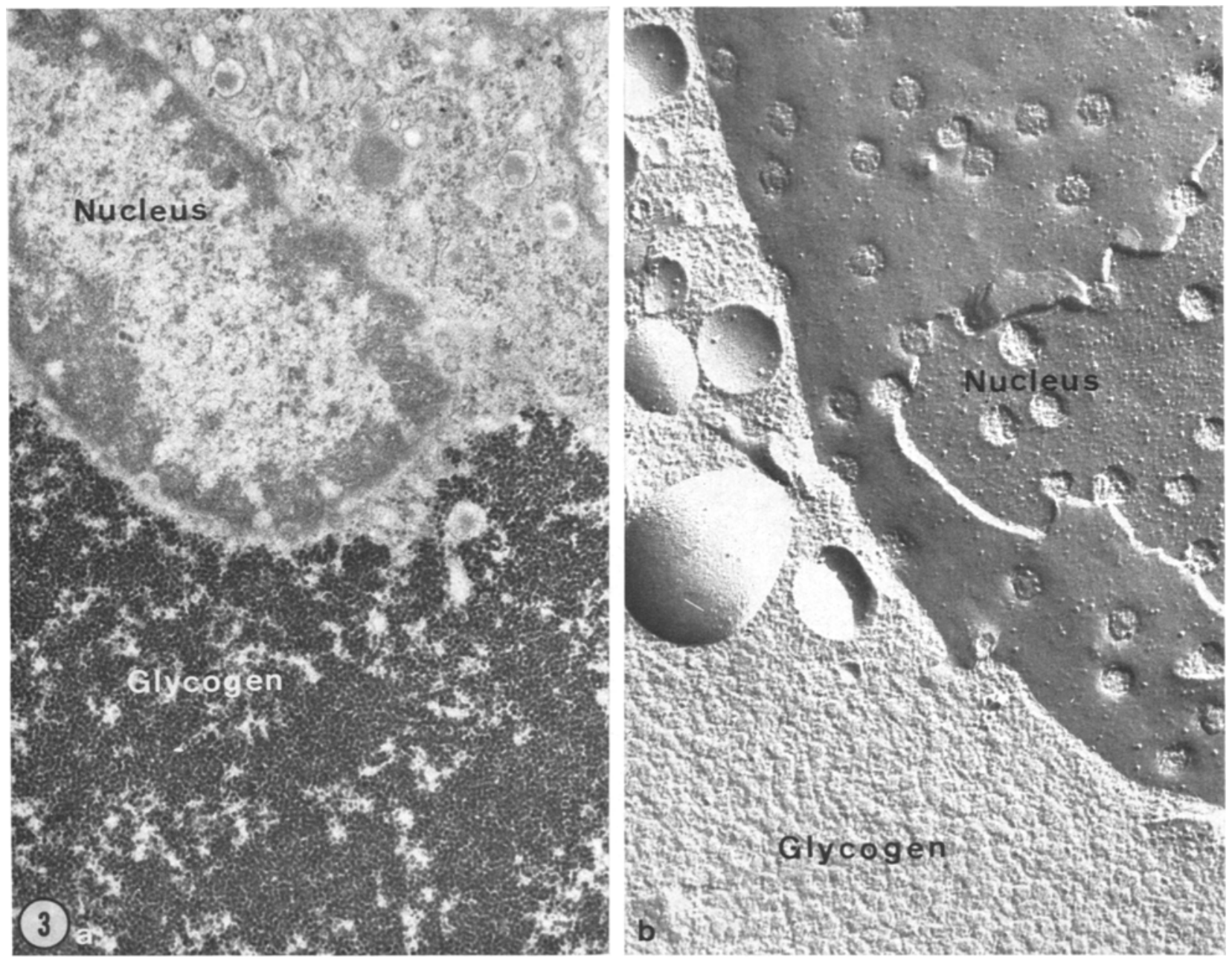

Fig. 3. Electron micrographs of thin-sectioned (a) and freeze-etched (b) B-cells from a diabetic (non-ketotic) Chinese hamster. The presence of glycogen deposits within the cytoplasm allows one to identify unambiguously a $B$-cell in freeze-etch replicas. $(\mathrm{a}=\times 19,000 ; \mathrm{b}=\times 49,000)$ 


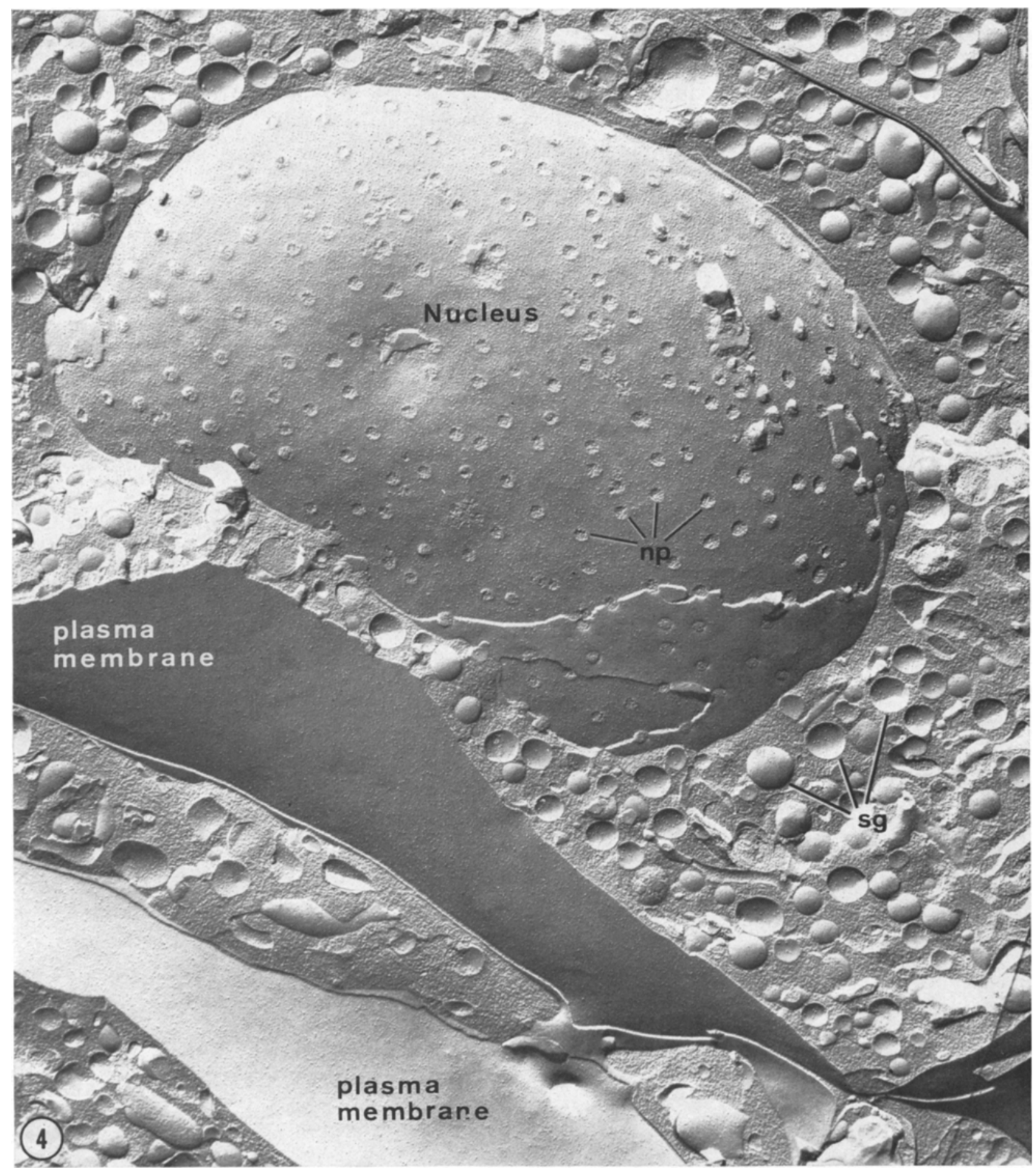

Fig. 4. Freeze-etch replica of a B-cell from a "control" Chinese hamster showing three-dimensional views of the fracture faces of plasma membranes, of the nuclear envelope and of cell organelles, mostly secretory granules $(\mathrm{sg})$. Notice the absence of bundle of filaments in the perinuclear region. $\mathrm{np}=$ nuclear pores. $(\times 22,000)$ 

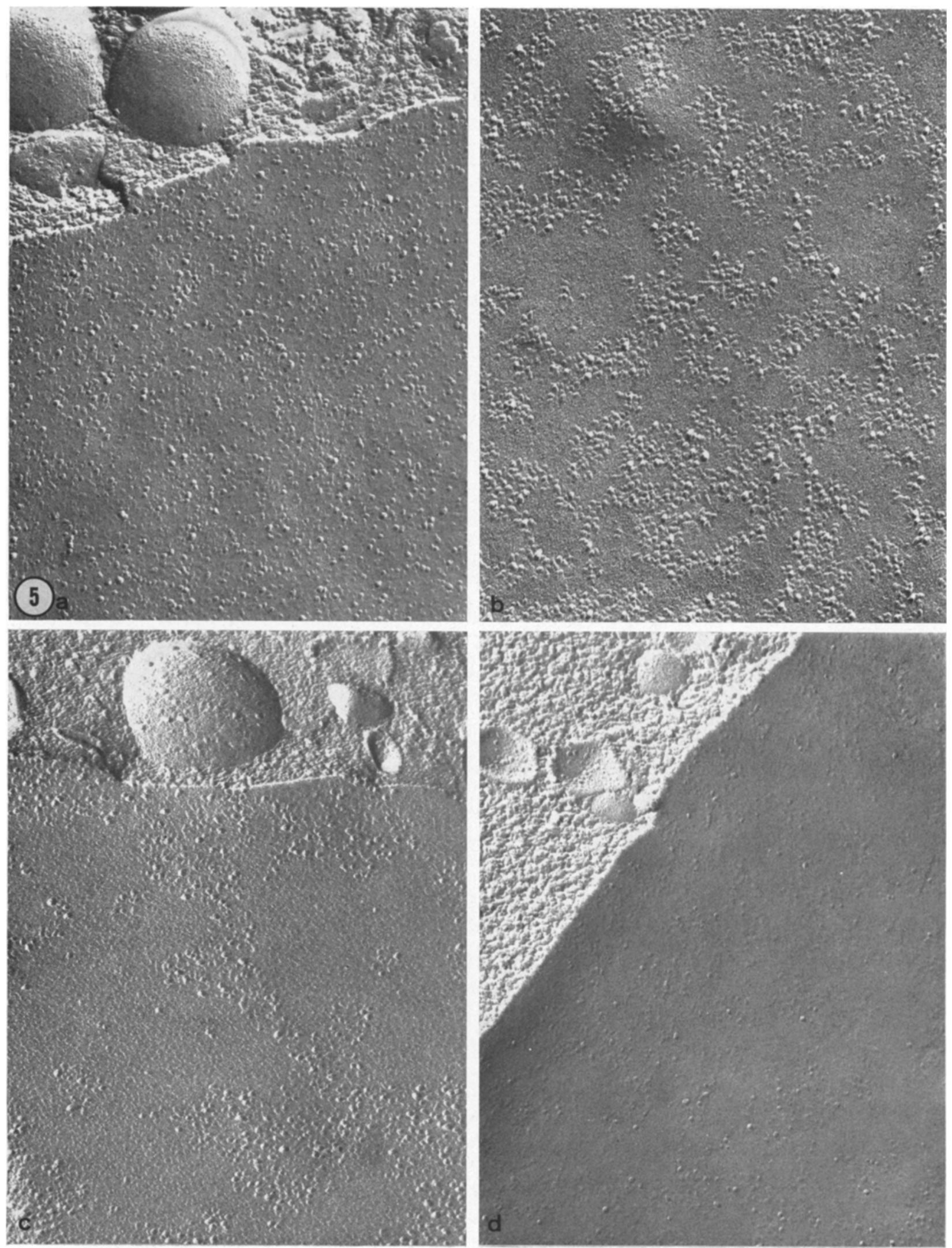

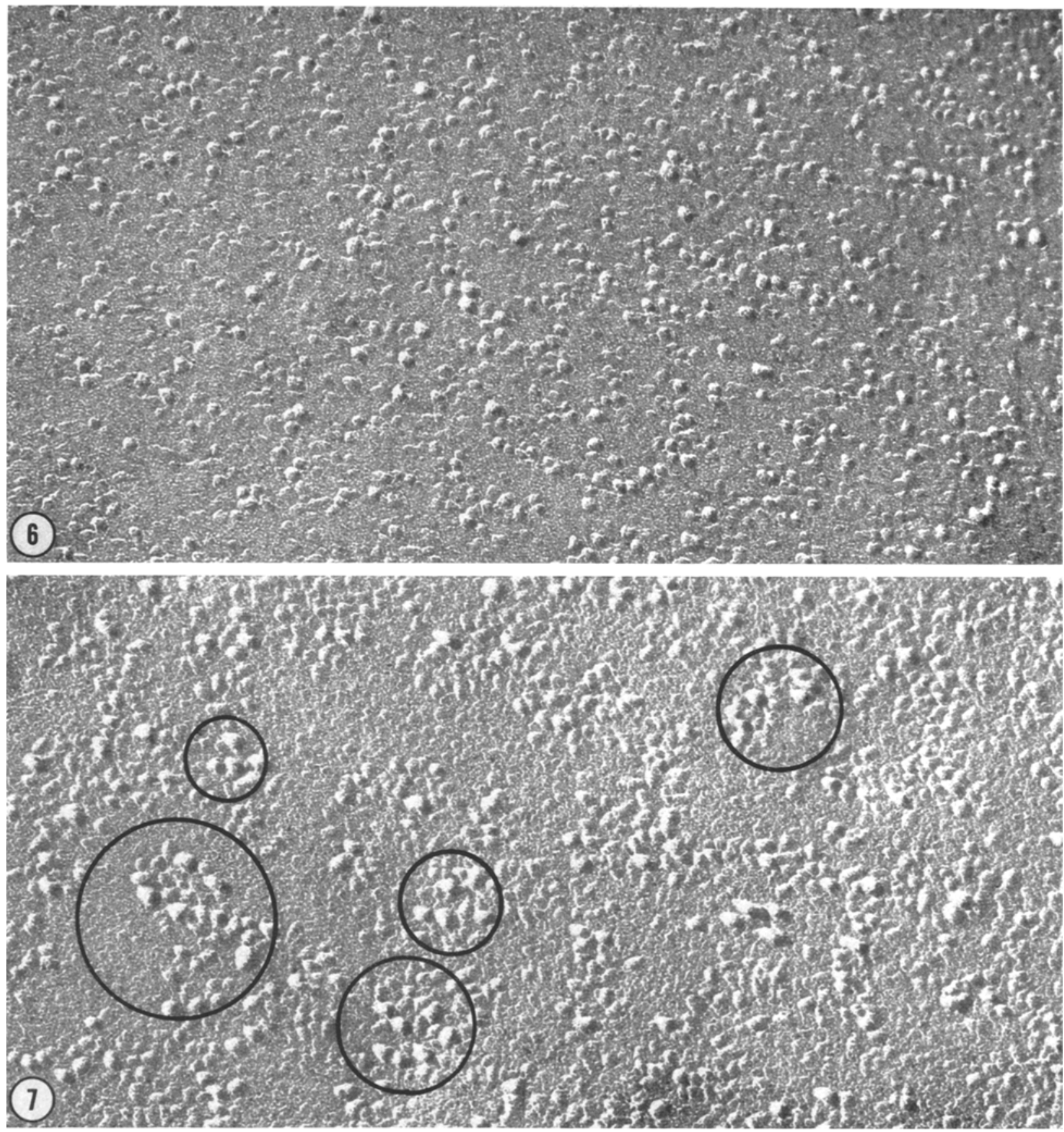

Fig. 5. Freeze-etch appearance of B-cell plasma membranes in "control" (a), diabetic (b) and ketotic (c and d) Chinese hamsters. Characteristically, freeze-etching process exposes the inner matrix of biological membranes and reveals intramembranous particles 60 to $180 \AA$ in diameter. In (a) the membrane-associated particles are randomly distributed. The number of particles found in membrane faces of the "control" Chinese hamster (about $1000 / \mu^{2}$ ) is only one half of that present in a similar membrane face of a normal rat (about 2000/ ${ }^{2}$ ) (1). In (b) the membrane-associated particles tend to be grouped in clusters. In (c) large areas of the exposed face of the plasma membrane appear devoid of particles. (d) shows an extreme degree of loss of membrane-associated particles. The counting of the mernbrane-associated particles on these pictures has given the following values: (a) 1056 particles $/ \mu^{2}$; (b) $1008 / \mu^{2}$; (c) $586 / \mu^{2}$; and (d) $284 / \mu^{2}$. (a, b, c and $d=\times 80,000$ )

Figs. 6 and 7. Fracture faces of the plasma membrane of B-cells in a "control" (Fig. 6) and ketotic (Fig. 7) Chinese hamster. Membrane-associated particles (encircled areas) are distinctly larger in the ketotic animal as compared with those of the "control" animal. ( $\times 178,000)$ 
SIZE-DISTRIBUTION OF MEMBRANE-ASSOCIATED PARTICLES OF B-CELLS ( PLASMA MEMBRANE A-FACE)
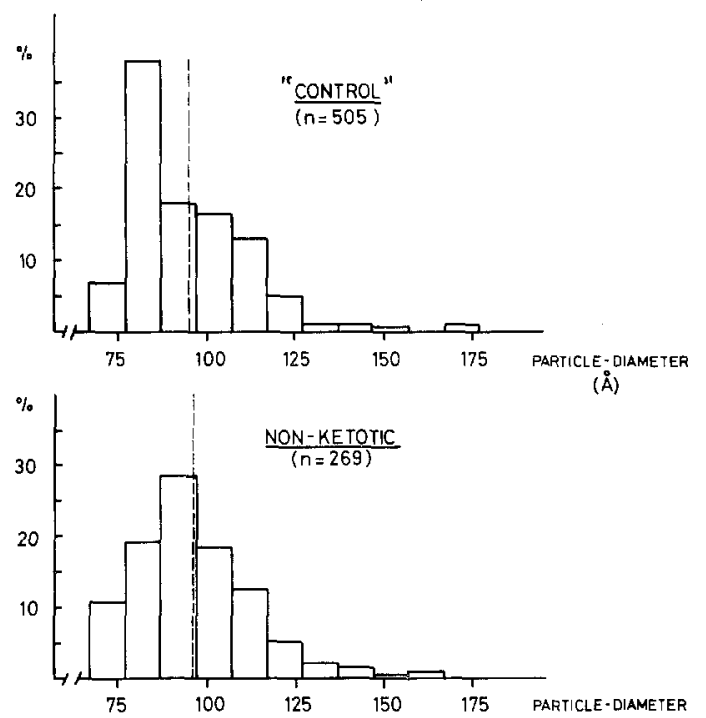

(A)

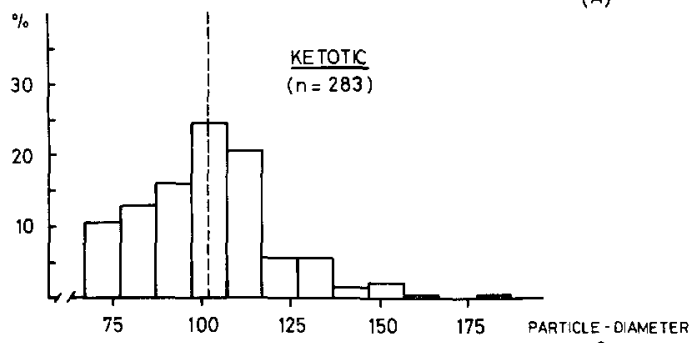

(ं)

Fig. 8. Frequency distribution (in \%) of particle sizes in plasma membranes of B-cells from "control", diabetic (non-ketotic) and ketotic Chinese hamsters ity of the cell (for review see ref. 7). The number and surface area of nuclear pores in A- and B-cell nuclei were therefore first assessed in our 3 experimental groups.

Fig. $2 \mathrm{a}$ shows a grazing section through the nuclear envelope. The nuclear pores are clearly visible but only a few of the total number present in the nuclear envelope are offered for examination and/or quantitation. By contrast (see Figs. 1 and 4), freeze-etching reveals the nuclear pores in large areas of the nuclear envelope where they appear as rims or dimples depending upon the face of the membrane exposed. In such pictures, it is possible to measure accurately both the density and size of the pores. Table 1 summarizes the results of these measurements. For each cell type, we have compared the data obtained in 5 pairs of control Chinese hamsters, 5 pairs of non-ketotic diabetic animals, and 5 pairs of ketotic hamsters. In A-cells, the density ${ }^{2}$ of nuclear pores was significantly higher in ketotic than in either control or non-ketotic animals. No significant difference was found between non-ketotic and control animals. In B-cells, the number of nuclear pores was also significantly increased in ketotic animals as compared to the controls. However, there was no significant difference between ketotic and non-ketotic animals.

The increase in the number of nuclear pores observed in A-cells of ketotic animals can be interpreted as reflecting an increased biosynthetic activity of glucagon-secreting cells. Such a finding is therefore compatible with the view that a relative increase in glucagon production contributes to the severity of the syndrome in the Chinese hamster. The slight increase in the number of nuclear pores observed in B-cells of diabetic Chinese hamsters is less easy to interpret, al-

2 Expressed either as number of pores $/ \mu^{2}$ or as $\%$ of surface area $/ \mu^{2}$ of the nuclear envelope.

Table 1. Quantitative data (mean $S E M$ ) on nuclear and plasma membranes in pancreatic $A$ - and $B$-cells of control (C), non-ketotic diabetic (NK) and ketotic diabetic $(K)$ Chinese hamsters

\begin{tabular}{|c|c|c|c|c|c|c|c|c|c|c|c|c|}
\hline & \multicolumn{6}{|l|}{ A-cell } & \multicolumn{6}{|c|}{ B-cell } \\
\hline & $\bar{C}$ & NK & $\mathrm{K}$ & $\mathrm{C} / \mathrm{NK}$ & $\mathrm{C} / \mathrm{K}$ & $\mathrm{NK} / \mathrm{K}$ & $\overline{\mathrm{C}}$ & NK & $\mathrm{K}$ & $\mathrm{C} / \mathrm{NK}$ & $\mathrm{C} / \mathrm{K}$ & $\mathrm{NK} / \mathrm{K}$ \\
\hline \multicolumn{13}{|l|}{ Nuclear pores } \\
\hline $\begin{aligned} \text { Number } & \left(\text { per } \mu^{2}\right) \\
& \pm S E M\end{aligned}$ & $\begin{array}{l}9.89 \\
0.46\end{array}$ & $\begin{array}{r}10.59 \\
0.46\end{array}$ & $\begin{array}{r}11.95 \\
0.27\end{array}$ & NS & $<0.005$ & $<0.02$ & $\begin{array}{l}8.93 \\
0.26\end{array}$ & $\begin{array}{l}9.94 \\
0.55\end{array}$ & $\begin{array}{r}10.15 \\
0.32\end{array}$ & $<0.1$ & $<0.02$ & NS \\
\hline $\begin{array}{l}\text { Surface area }(\% \\
\left.\text { per } \mu^{2}\right) \quad \pm S E M \\
\end{array}$ & $\begin{array}{l}7.46 \\
0.35 \\
\end{array}$ & $\begin{array}{l}7.99 \\
0.35 \\
\end{array}$ & $\begin{array}{l}9.01 \\
0.20 \\
\end{array}$ & NS & $<0.005$ & $<0.02$ & $\begin{array}{l}6.44 \\
0.19 \\
\end{array}$ & $\begin{array}{l}7.17 \\
0.39 \\
\end{array}$ & $\begin{array}{l}7.32 \\
0.23 \\
\end{array}$ & $<0.1$ & $<0.02$ & NS \\
\hline \multicolumn{13}{|l|}{$\begin{array}{l}\text { Plasma membrane } \\
\text { associated particles }\end{array}$} \\
\hline $\begin{array}{l}\text { Number in A-face } \\
\left(\text { per } \mu^{2}\right) \quad \pm S E M\end{array}$ & $\begin{array}{r}1186 \\
97\end{array}$ & $\begin{array}{r}1071 \\
50\end{array}$ & $\begin{array}{r}920 \\
16\end{array}$ & NS & $<0.005$ & $<0.01$ & $\begin{array}{r}1217 \\
29\end{array}$ & $\begin{array}{r}948 \\
49\end{array}$ & $\begin{array}{r}767 \\
60\end{array}$ & $<0.005$ & $<0.005$ & $<0.05$ \\
\hline $\begin{array}{l}\text { Number in B-face } \\
\left(\text { per } \mu^{2}\right) \quad \pm S E M\end{array}$ & $\begin{array}{r}252 \\
50\end{array}$ & $\begin{array}{r}257 \\
67\end{array}$ & $\begin{array}{r}368 \\
82\end{array}$ & NS & NS & NS & $\begin{array}{r}248 \\
25\end{array}$ & $\begin{array}{r}194 \\
28\end{array}$ & $\begin{array}{r}298 \\
94\end{array}$ & NS & NS & NS \\
\hline $\begin{array}{l}\text { Mean size in A- } \\
\text { face }(\AA) \quad \pm S E M\end{array}$ & $\begin{array}{r}98.5 \\
1.0 \\
\end{array}$ & $\begin{array}{r}99.2 \\
1.0 \\
\end{array}$ & $\begin{array}{r}100.6 \\
1.6 \\
\end{array}$ & NS & NS & NS & $\begin{array}{r}95.0 \\
0.6 \\
\end{array}$ & $\begin{array}{r}96.5 \\
0.9 \\
\end{array}$ & $\begin{array}{r}102.1 \\
1.1 \\
\end{array}$ & $<0.1$ & $<0.005$ & $<0.001$ \\
\hline
\end{tabular}

The statistical significance of differences between groups is indicated in each case (NS: $P>0.15$ ). 


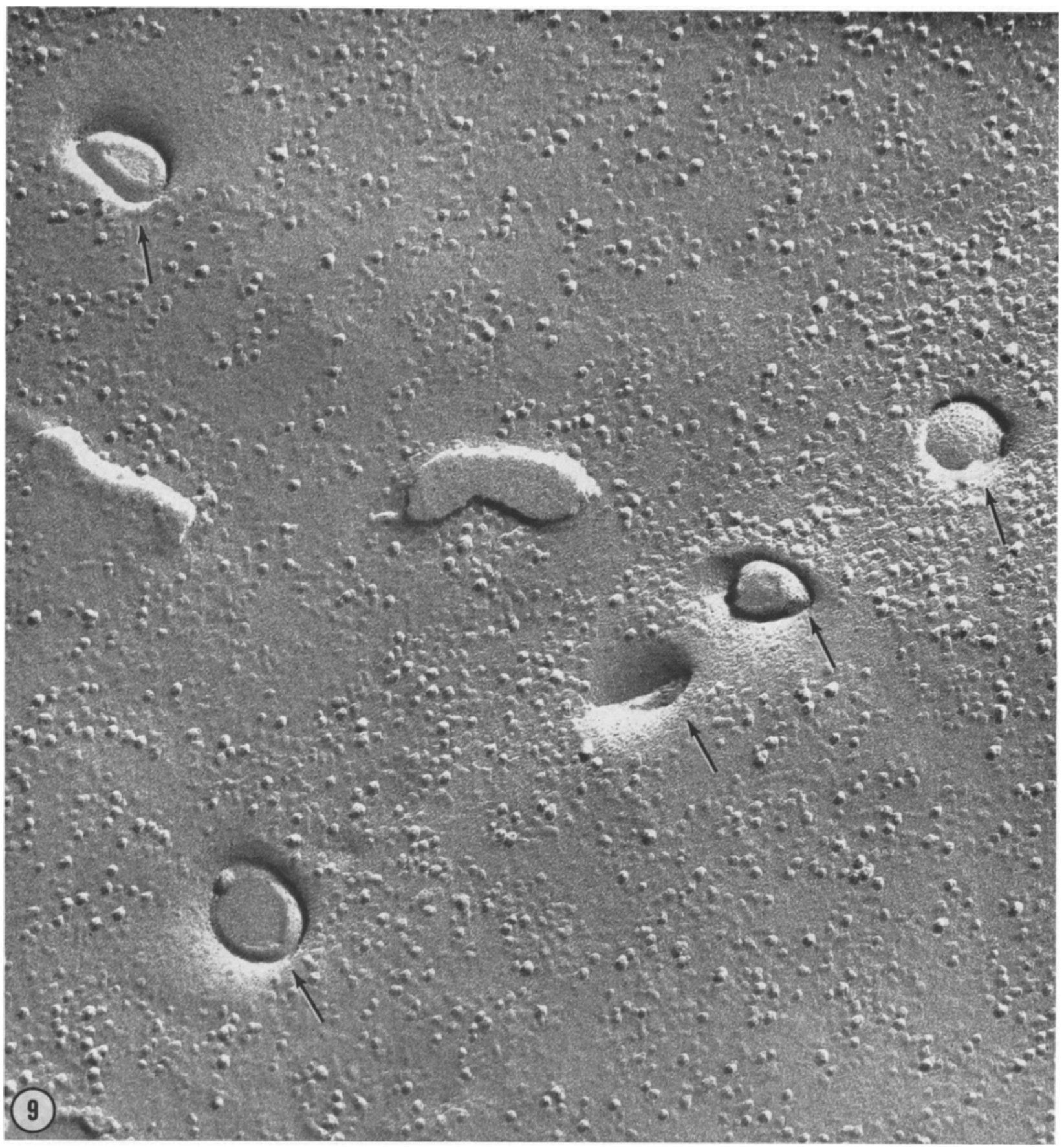

Fig. 9. Plasma membrane of a B-cell from a diabetic (ketotic) Chinese hamster. The arrows point to exocytotic (emiocytotic) stomata, most of which show protruding granule-cores. Stomata are surrounded by areas of membrane deprived of membrane-associated particles. Several areas of the membrane outside the exocytotic events also show a variable degree of particle depletion. $(\times 143,000)$ 
though it suggests a sustained biosynthetic activity of the insulin producing cells. This is also consistent with previous claims that the relative insulin deficiency observed in these animals cannot be ascribed to a primary defect in the synthesis of the hormone [8].

The other membrane compartment selected for the study in freeze-etching was the plasma membrane of A- and B-cells. In the insular cells, as in other cell types sofar studied, the inside of the membranes appears structurally differentiated into smooth areas earrying particles 60 to $180 \AA$ in diameter. It is now widely accepted that these particles represent, at least in part, proteins which together with lipids are the building blocks of the membrane. When various membrane systems are studied by freeze-etching, differences in the number, distribution and arrangement of these particles are noted. For example, metabolically active membranes such as the $\mathrm{B}$-cell membrane possess numerous particles, while inactive membranes, such as the myelin around the nerve axons, which acts as an inert insulator, contain only few particles. Thus, the number of particles seen in freeze-etched preparations seem to be directly related to the degree of functional complexity of the membrane [9].

We have investigated the density, size and pattern of distribution of such particles in both A- and B-cells of normal and diabetic Chinese hamsters (Table 1).

In B-cells, a progressive and highly significant fall in the density of membrane-associated particles occurred (up to $35 \%$ of the control values) in parallel with the severity of the diabetic state (Fig. 5). A similar, although less marked trend was seen in the A-cells of the most severely diabetic Chinese hamsters. In the plasma membrane of B-cells, the mean size of particles also tended to shift to larger values as diabetes became more severe (Figs. 6 to 8 ). A third change observed in

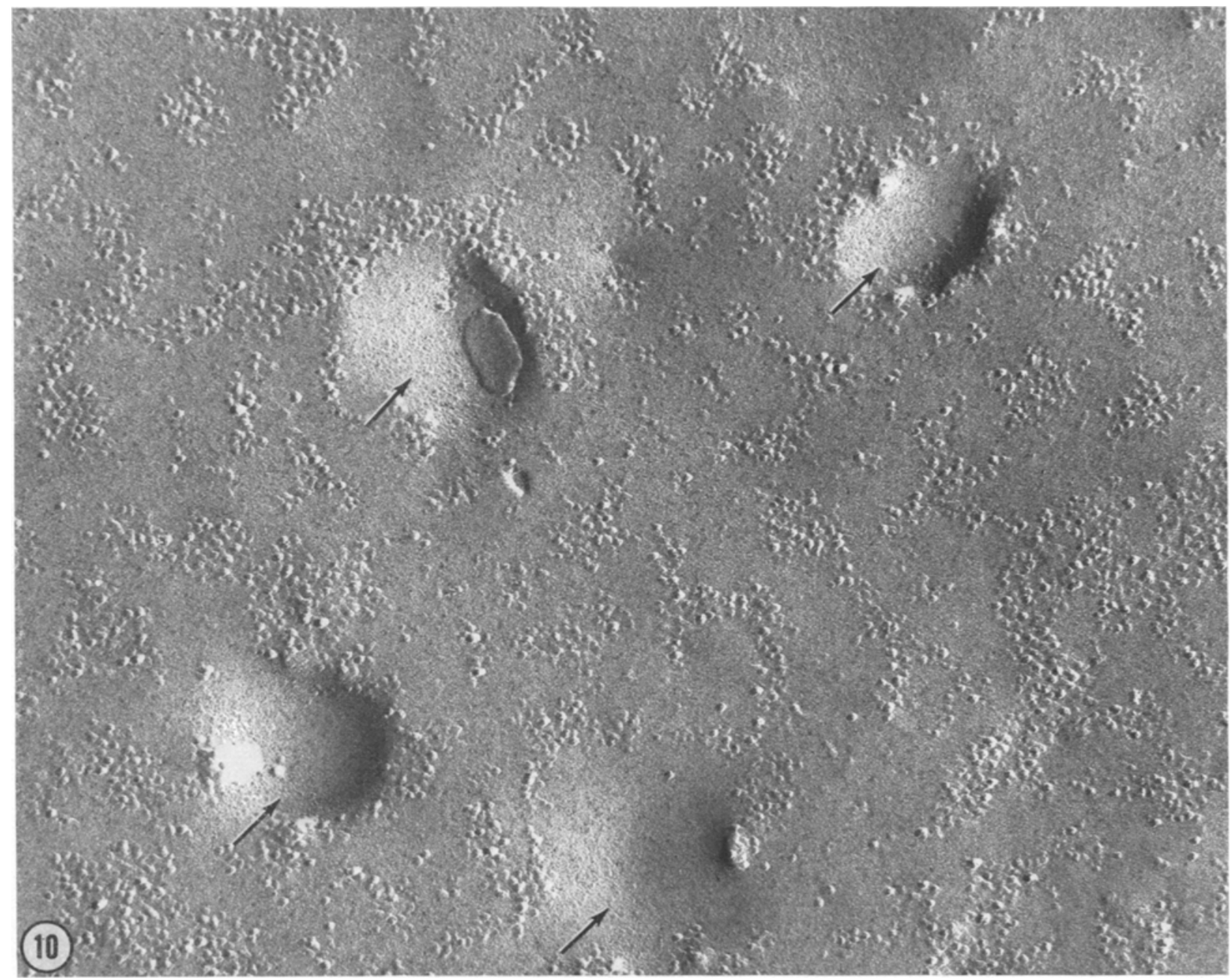

Fig. 10. Plasma membrane of a B-cell from a diabetic (ketotic) Chinese hamster. The membrane-associated particles are distributed in clusters separated by smooth areas. The arrows point to sites of exocytotic events (probably at a later stage than that shown in Fig. 9). At these sites, the membrane face is also conspicuously deprived of membrane-associated particles. $(\times 96,000)$ 
the B-cell membrane of diabetic animals was a modification in the pattern of distribution of these particles (see Fig. 5). Fig. 5a shows the plasma membrane of a B-cell from a normoglycemic Chinese hamster. In this membrane, the particles are distributed in a random pattern and are well separated from one another. By contrast, the particles in diabetic animals (Figs. $5 \mathrm{~b}-\mathrm{c}$ ) are clustered and leave completely smooth areas in the membrane. One possible cause for these smooth, particle-free areas could be a repetitive exocytosis (emiocytosis) (Figs. 9 and 10), coupled with an impairment of the redistribution and/or turnover of the membrane-associated particles. Indeed, the incorporation of the smooth membrane of the granule in the richly particulated plasma membrane [1], if not balanced by synthesis and redistribution of new particles, would lead to the progressive dilution of the particles in the plasma membrane described above.

In summary, the present account suggests that the progression of diabetes in Chinese hamsters is associated with an altered organization of membrane systems in pancreatic endocrine cells, at the level of both the nuclear envelope and the plasma membrane. These ultrastructural changes may occur at an earlier stage of the disease in $B$ - than in A-cells. Further investigations are now required to assess fully the significance of these alterations. Nevertheless, the present data appear sufficiently promising to warrant further use of this novel approach for the study of islet pathophysiology in spontaneous diabetes.

Acknowledgements. We thank Mrs. M. Sidler-Ansermet and G. Boljevic and Mr. M. Bernard for their precious help.

\section{References}

1. Orci, L.: A portrait of the pancreatic B-cell. Diabetologia 10, 163-187 (1974)

2. Ferner, H.: Das Inselsystem des pancreas. p. 119. Stuttgart: G. Thieme 1952

3. Lacy, P. E., Kostianowski, M. : Method for the isolation of intact islets of Langerhans from the rat pancreas. Diabetes 16, 35-39 (1967)

4. Moor, H., Mühlethaler, K.: Fine structure in frozenetched yeast cells. J. Cell Biol. 17, $609-628$ (1963)

5. Orci, L., Stauffacher, W., Renold, A.E., Rouiller, Ch. The ultrastructural aspect of A-cells of non-ketotic and ketotic diabetic animals: indications for stimulation and inhibition of glucagon production. In: Current topies on glucagon. (Eds. Austoni, M., Scandellari, C., Federspil, G., Trisotto, A.), pp. 15-30. Padova: CEDAM 1971

6. Orei, L., Stauffacher, W., Dulin, W.E., Rouiller, Ch. Ultrastructural changes in A-cells exposed to diabetic hyperglycaemia - Observations made on pancreas of Chinese hamsters. Diabetologia 6, $199-206$ (1970)

7. Feldherr, C.M.: Structure and function of the nuclear envelope. Advances in cell and molecular biology (ed. E.S. DuPraw), 273-307. New York and London: Academic Press 1972

8. Malaisse, W., Malaisse-Lagae, F., Gerritsen, G.C., Dulin, W.E., Wright, P.H.: Insulin secretion in vitro by the pancreas of the Chinese hamster. Diabetologia 3, $109-114(1967)$

9. Branton, D.: Membrane structure. Ann. Rev. Plant. Physiol. 20, 209-238 (1969)

Prof. L. Orei

Institut d'Histologie et

d'Embryologie

Ecole de Médecine

CH-1211 Genève 4

Switzerland 